\title{
A INJUSTIÇA LEGAL COMO VÍCIO DO JUIZ QUE JULGA: UMA CONTINUIDADE NA DIFERENÇA PARADIGMÁTICA ENTRE SÃO TOMÁS E HABERMAS
}

José Marcos Miné Vanzella

Doutor em Filosofia pela Universidade Gama Filho (Rio de Janeiro) . Professor e Pesquisador no Programa de Mestrado em Direito do Centro Unisal - U.E. de Lorena (SP). E-Mail: enimine@gmail.com

Lino Rampazzo

Doutor em Teologia pela Pontificia Università Lateranense (Roma). Professor e Pesquisador no Programa de Mestrado em Direito do Centro Unisal - U.E. de Lorena (SP). E-mail: lino.rampazzo@uol.com.br

\section{Resumo}

Este artigo pretende identificar certa filiação crítica do pensamento habermasiano à tradição do pensamento tomasiano, através da aderência aos elementos fundamentais da pessoa, da moral e da injustiça legal como vício do juiz que julga. No primeiro momento analisa o pensamento filosófico tomasiano no que diz respeito à "Injustiça" e à "Injustiça do juiz no julgar”, a partir de uma visão geral da Suma Teológica. Com referência à primeira questão, são analisados quatro artigos: se a injustiça é um vício especial; se praticar atos injustos é próprio do injusto; se podemos sofrer injustiça voluntariamente e se a injustiça é genericamente pecado mortal. Também a segunda questão estuda quatro artigos, a saber: se podemos julgar justamente quem não depende de nós; se é lícito ao juiz, baseado no que lhes expóem, julgar contra a verdade que conhece; se o juiz pode condenar justamente quem náo é acusado e se pode licitamente relaxar a pena. No segundo momento apresenta o pensamento de Habermas sobre a injustiça do juiz que julga. Mostra-se a filiação de Habermas à filosofia da pessoa moral. A pessoa do juiz participa de uma realidade mediada simbolicamente e experimentada nesta mediação, a qual é medida da imputação de sua responsabilidade moral. Esta é repensada através de sua socialização e introdução num mundo da vida simbolicamente mediado. Acrescenta-se a ignorância da lei de São Tomás à modalidade de injustiça legal como vício do juiz que julga por ignorância paradigmática do direito. Distingue a superação do solipsismo metódico que exige do juiz decisóes bem fundamentadas: estas se expressam como bons argumentos perante a comunidade jurídica. Tal posição desemboca na compreensão dos discursos de aplicação 
com aperfeiçoamento da ponderação do procedimento argumentativo. Mostra-se a aderência de Habermas aos temas postos por São Tomás, sua atualização crítica e tradução.

\section{Palavras-chave}

São Tomás; Habermas; Injustiça Legal; Juiz que julga.

\section{Riassunto}

Questo articolo artigo si propone di identificare una certa filiazione critica del pensiero di Habermas con la tradizione del pensiero di San Tommaso, attraverso l'aderenza agli elementi fondamentali della persona, della morale e dell'ingiustizia legale come vizio del giudice che giudica. Nel primo momento analizza il pensiero filosofico di San Tommaso sui temi dell' "Ingiustizia" e dell' "Ingiustizia del giudice nel giudicare", a partire da una visione generale di quest'opera. Riguardo alla prima questione, si studiano quattro articoli: se l'ingiustizia è un vizio speciale; se è proprio dell'ingiusto praticare atti ingiusti; se possiamo soffrire l'ingiustizia volontariamente e se l'ingiustizia genericamente è un peccato mortale. Pure la seconda questione studia quattro articoli, cioè: se possiamo giudicare giustamente chi non dipende da noi; se è lecito al giudice, basandosi in quello che gli espongono, giudicare contro la verità che conosce; se il giudice può condannare giustamente chi non è accusato e se può licitamente ridurre la pena. Nel secondo momento presenta il pensiero di Habermas riguardo all'ingiustizia del giudice che giudica. Mostra il legame di Habermas con la filosofia della persona morale. La persona del giudice partecipa di una realtà mediata simbolicamente e sperimentata in questa mediazione, che è misura dell'imputazione della sua responsablità morale. Questa è ripensata attraverso la sua socializzazione e l'introduzione in un mondo della vita mediato simbolicamente. Si aggiunge il tema dell'ignoranza della legge in San Tommaso alla modalità di ingiustizia legale come vizio del giudice che giudica per ignoranza paradignatica del diritto. Distingue il superamento del solipsismo metodico che esige da parte del giudice decisioni ben fondate: queste si esprimono come argomenti validi davanti alla comunità giuridica. Tale posizione sfocia a comprendere i discorsi di applicazione con perfezionamento della ponderazione della procedura argomentativa. Si mostra l'aderenza di Habermas ai temi posti da San Tommaso, come pure la sua attualizzazione critica e la sua interpretazione.

\section{Parole chiave}

San Tommaso; Habermas; Ingiustizia Legale; Giudice che giudica.

\section{Introdução}

O presente ensaio investiga a questão da injustiça legal, como vício do juiz que julga, procurando estabelecer uma linha de continuidade na diferença paradigmática entre São 
Tomas e Habermas. Questiona-se se é possível encontrar alguma modalidade de injustiça cometida pelo juiz, refletindo a partir de Habermas, que possa aprimorar a consciência moral dos juízes, dando continuidade em outro paradigma ao trabalho iniciado por São Tomas. Deste modo pretende-se contribuir para o aprimoramento da consciência moral da atividade da magistratura.

Inicialmente, a primeira parte do artigo questiona a injustiça e o Juiz que julga na Suma Teológica. Aborda-se o tema nos três momentos seguintes: o tema da injustiça na Suma Teológica; a injustiça como vício; e por fim a injustiça do juiz que julga.

$\mathrm{Na}$ segunda parte aborda-se a injustiça legal como vício do juiz que julga, a partir do pensamento de Habermas nos quatro momentos seguintes: faz-se inicialmente a distinção do paradigma de Habermas e o acesso à questáo da pessoa moral; em seguida investiga-se a modalidade da injustiça legal como vício do juiz que julga, por ignorância paradigmática do direito; aborda-se então a superação do solipsismo metódico a partir da filosofia de Apel, parceiro de Habermas na ética do discurso, e a pertença do juiz à comunidade; por fim procura-se apresentar a questão dos discursos de aplicação, o juiz, a ponderação e o procedimento.

\section{A Injustiça e o Juiz injusto na Suma Teológica}

\subsection{O Tema da Injustiça na Suma Teológica}

Para entender melhor as questóes 59 e 67, da segunda parte da Segunda Parte da Suma Teológica, que tratam, respectivamente, da "injustiça” e da "injustiça do juiz no julgar", apresenta-se o esquema geral da obra e, particularmente, o espaço significativo que, nela, São Tomás dá para a temática da justiça e da injustiça.

A Suma Teológica (Summa Theologiae) é a obra principal de São Tomás de Aquino (1225-1274): contém 512 questóes e 2.669 artigos. A estrutura dessa obra é articulada em três Partes. A Primeira Parte, dogmática, sobre Deus em si mesmo, sobre o mistério da Trindade e sobre a atividade criadora de Deus (questôes 1-119).

Na Segunda Parte, moral, São Tomás considera o homem, impelido pela graça, na sua aspiração de conhecer e amar a Deus para ser feliz no tempo e na eternidade. Esta Parte, por sua vez, está subdividida em mais duas partes: a primeira parte da Secunda (prima secundae I-II) e a secunda parte da Secunda (secunda secundae II-II).

Primeiro (I-II), ele apresenta os princípios teológicos do agir moral, estudando como, na liberdade de escolha humana para praticar o bem, integram-se a razão, a vontade e as paixóes, às quais se acrescenta a força que dá a graça de Deus, bem como a ajuda que é oferecida também pela lei moral (questóes 1-114). 
Sobre este fundamento, São Tomás delineia a fisionomia do homem que vive segundo o Espírito e que se torna, assim, um ícone de Deus (II-II). Aqui, ele estuda as três virtudes teologais - fé, esperança e caridade -, seguidas do agudo exame de mais de cinquenta virtudes morais, organizadas em torno das quatro virtudes cardeais - prudência, justiça, temperança e fortaleza. Termina, então, com a reflexão sobre as diferentes vocaçóes na Igreja (questôes 1-189).

Na terceira Parte da Suma, novamente dogmática, São Tomás estuda o Mistério de Cristo por meio do qual pode-se alcançar novamente a Deus Pai. Nesta seção, escreve páginas sobre o Mistério da Encarnação e da Paixão de Jesus e sobre os sete sacramentos (questôes 1-90). (TORREL, 2003).

Os temas específicos da Justiça e da Injustiça são tratados na segunda parte da Segunda Parte. Mais especificamente aparecem no capítulo das virtudes "cardeais", a saber, a prudência, a justiça, a fortaleza e a temperança. A esse respeito, ele dedica 10 questóes para tratar da prudência (questôes 47-56), 66 questóes relativas à justiça (questóes 57122), 18 questóes sobre a fortaleza (questóes 123-140) e, por fim, 30 questôes sobre a temperança (questóes 141-170).

Em suma, ele fala mais sobre a justiça do que sobre as outras três virtudes cardeais, que somam 58 questóes. E, falando da justiça, ele reflete também sobre o vício oposto, a saber a injustiça, nos seguintes temas específicos, dos quais indicam-se as questóes correspondentes, a seguir (q.), como se encontram na Suma.

1. A Justiça em si mesma: o direito, objeto da justiça (q. 57); a justiça (q. 58); a injustiça (q. 59); o juízo (q. 60). Em seguida, a Suma trada da justiça comutativa e distributiva (q. 61-62).

2. Vícios opostos à justiça:

a) à justiça distributiva: a acepção de pessoas (q. 63);

b) à justiça comutativa: o homicídio (q. 64); a mutilação, o açoite e o encarceramento (q. 65); o furto e o roubo (q. 66); a injustiça do juiz no julgar (q. 67); a acusação injusta (q. 68); a injustiça do acusado (q. 69); a injustiça da testemunha (q. 70); a injustiça dos advogados (q. 71); a injúria (q. 72); a difamação (q. 73); o mexerico (q. 74); a zombaria (q. 75); a maldição (q. 76); a fraude nas compras ou vendas (q. 77); a usura nos empréstimos (q. 78).

Colocaram-se grifadas as questôes que vão ser consideradas neste estudo.

\subsection{A Injustiça como Vício na Suma Teológica}

A questão 59 leva por título: De Iniustitia, Sobre a Injustiça; e pretende discutir quatro artigos: a) se a injustiça é um vício especial (art. I); b) se praticar atos injustos é 
próprio do injusto (art. II); se podemos sofrer injustiça voluntariamente (art. III); d) se a injustiça é genericamente pecado mortal (art. IV).

Devido à necessária brevidade do presente estudo, será estudada a resposta principal dos mesmos, entrando apenas algumas vezes nas particularidades das objeçôes, que são apresentadas em todos os artigos da Suma, com uma correspondente resposta.

Na resposta ao questionamento do primeiro artigo, São Tomás afirma que a injustiça ilegal é um vício especial porque despreza o bem comum, que é o objeto especial da justiça legal. Mas, quando o homem despreza o bem comum, "pode ser arrastado a todos os pecados". Por isso "todos os vícios, enquanto repugnam ao bem comum, têm natureza de injustiça, isto é, são como derivados dela". Neste sentido, a injustiça, que engloba todos os vícios, não é um "vício especial”, mas "geral”, pois todo vício é uma forma de injustiça. Considerando, porém, a injustiça na sua modalidade de implicar uma "certa desigualdade em relação a outrem", neste caso a injustiça "tem uma especial matéria e é um vício particular oposto à justiça particular".

Percebe-se, pois, que São Tomás discutiu, especificamente, a injustiça como vício em três vertentes básicas: a primeira como uma ilegalidade, enquanto um vício especial; a segunda como todas as ilegalidades, enquanto um vício geral; e a terceira como desigualdade, enquanto um vício particular. Além disso, não se pode esquecer que a sua obra é, antes de tudo, teológica: por isso faz referência ao conceito especificamente teológico do "pecado".

Falar de injustiça, de algum modo, é relacioná-la com a própria justiça, um hábito virtuoso. O mesmo pode ser dito da injustiça: é também um hábito, mas vicioso. Não é por outra razão que, na concepção tomasiana, a injustiça é, por assim dizer, "um vício com um único propósito, o de estar deliberadamente disposto a opor-se àquilo que é exigido pela justiça” (MACINTYRE, 1991, p. 223). Embora possa ser viciada de muitas maneiras, para São Tomás, em geral, a perversão da reta razão (recta ratio) é o modo mais recorrente de se afastar da justiça e aproximar-se da injustiça (BITTAR; ALMEIDA, 2010, p. 242).

O segundo artigo questiona se deva considerar-se injusto quem comete injustiça.

$\mathrm{Na}$ resposta São Tomás explica que é objeto da justiça "uma igualdade relativa às coisas exteriores". Paralelamente, a injustiça é uma "desigualdade pela qual damos a outrem mais ou menos do que lhe compete". Com essa premissa, pode acontecer que alguém cometa injustiça, sem ser injusto: e isso por duas razóes. Primeiro, por falta de relação entre a ação e seu objeto próprio. Neste sentido, nos atos relativos a um fim, a intenção é essencial. Em outros termos, precisa querer um determinado efeito. Por isso, quem pratica uma injustiça, sem a intençáo de praticá-la, o que poderia acontecer em quem age por ignorância, ou seja em quem pensa não fazer um ato injusto, essa pessoa náo pratica 
injustiça, "em si e formalmente falando", mas só "por acidente e apenas materialmente". Em segundo lugar, pode acontecer que náo haja correlação entre o ato e o hábito. Isso se daria, por exemplo, quando a origem do ato é uma paixão, como, por exemplo, a ira ou a concupiscência Por isso, é injusto apenas quem comete a injustiça intencional e propositalmente, por ter o hábito da injustiça. Mas pode acontecer que alguém faça injustiça sem intenção, ou por paixão: neste caso a pessoa não tem o hábito da injustiça.

O terceiro artigo questiona se podemos sofrer injustiça voluntariamente.

$\mathrm{Na}$ resposta São Tomás faz distinção entre a ação e a paixão: a primeira procede da vontade, que é o princípio dos atos humanos; e a segunda da natureza. Na primeira situação, o homem é "agente" e na segunda é "paciente", chegando a sofrer contra a própria vontade. Conclui-se, pois, que a injustiça, propriamente falando, provém de um ato voluntário: e "ninguém pode fazê-la senão voluntariamente, nem sofrê-la senão involuntariamente". Porém, "quase materialmente falando, podemos fazer sem querer o que é, em si mesmo, injusto; e podemos sofrê-lo voluntariamente, como quando damos a outrem, por nossa vontade, mais do que lhe devemos".

São Tomás sempre faz questão de distinguir os diferentes casos e situaçóes. Partindo, então, do princípio do que "o fato de alguém fazer uma injustiça e, correspondentemente, o fato de uma outra pessoa sofrer a injustiça são termos correlatos", considera a possibilidade de alguém que, formalmente falando, comete a injustiça, pois tem a intenção de cometê-la, mas o outro náo a sofre, por sofrê-la voluntariamente; e, ao inverso, alguém que sofre uma injustiça por sofrê-la contra a vontade, mas na situação em que alguém a fez por ignorância, só materialmente e não formalmente.

$\mathrm{O}$ quarto artigo questiona se a injustiça é genericamente pecado mortal.

Na resposta São Tomás lembra já ter tratado da diferença dos pecados numa questão da primeira parte da Segunda Parte (q. 72, art. 5), na qual tinha afirmado que se considera pecado mortal o que contraria a caridade. Mas, como todo dano causado a outrem repugna, em si mesmo, a caridade, conclui-se que a injustiça, caracterizada em causar dano a outrem, "é pecado genericamente mortal".

O advérbio de modo "genericamente" é explicado na resposta à primeira objeção. Nesta ele considera a situação de quem, ignorando as "circunstâncias particulares", comete uma injustiça. Trata-se, neste caso, de uma injustiça "por acidente", que "merece perdão". Diferente seria o caso da "ignorância de direito".

O significa a expressão "ignorância de direito"?

A questão da "ignorância de direito" remonta ao direito romano. Em geral, os jurisconsultos romanos não a admitiam. Para eles, como regra, a ignorância de direito não deve ser considerada tal como a ignorância de fato: isso porque há muita diferença entre conhecer o fato e conhecer o direito. Como o direito, de regra, deve ser definido e certo, 
não permite escusas àqueles que o ignoram. Mas o conhecimento dos fatos, de regra, pode escapar aos mais bem avisados. Por isso, a ignorância de fato merece razoáveis escusas. Dessa distinçáo decorre a discussão daquilo que deve ser tido como justo ou não, quando se trata de acarretar prejuízos. Na jurisprudência romana é entendido como escusável e justo não se responsabilizar a invencível ignorância de fato de alguém; ao contrário, a ignorância do direito é inescusável e é injusto deixar de responsabilizar aquele que a comete. No Digesto, ficou assentada a regra de que a ignorância de direito prejudica, e a de fato não (JUSTINIANO, 1972, p. 99).

Tem-se em consideração que há razões de justiça que justificam tratamento diferenciado entre ignorância de direito e de fato, com suas respectivas consequências. Entendese que é mais fácil conhecer o direito do que os fatos. Assim, não seria princípio de justiça escusar, de modo igual, ambas as ignorâncias. Se é mais fácil conhecer o direito do que os fatos, nada mais justo que a ignorância do direito não aproveite, com facilidade, quem nela incide, enquanto a ignorância de fato, pelas suas circunstâncias peculiares, justifica

que aproveite, sem prejuízos, aqueles que nela incorrem. É por isso que se tem dito que os romanos, com esta distinção cuidadosa, estabeleceram duas regras opostas uma à outra, porque fundadas em razóes opostas (PITTA, 1871, p. 18-19).

\subsection{A Injustiça do Juiz que Julga}

A questão 67 leva por título: De Iniustitia Iudicis in iudicando, Da Injustiça do Juiz no julgar e pretende discutir quatro artigos: a) se podemos julgar justamente quem não depende de nós (art. I); b) se é lícito ao juiz, baseado no que lhes expóem, julgar contra a verdade que conhece (art. II); c) se o juiz pode condenar justamente quem náo é acusado (art. III); d) se pode licitamente relaxar a pena (art. IV).

$\mathrm{Na}$ resposta ao questionamento do primeiro artigo, Sáo Tomás afirma que a sentença do juiz pode ser considerada como uma "lei particular aplicada a um fato particular". Neste sentido "deve ter força coativa” para ser eficaz, à semelhança da lei geral. Mas "na ordem das coisas humanas" somente a autoridade pública tem o poder coativo. Este poder, por sua vez, pode ser ordinário, ou "em virtude de uma comissão". Por tudo isso, quem não está investido de uma destas modalidades do poder público não pode julgar.

$\mathrm{O}$ artigo tem, entre outros objetivos, o de apontar para os limites da autoridade judicial. É curioso como São Tomás já anunciava algo que se consagrou como um princípio fundamental da jurisdição: o juízo natural. Isso significa que a autoridade judicial deve estar pré-constituída, investida de seu poder jurisdicional, para que todos os que a ela se submetem não sejam surpreendidos com juízos de exceção. O julgador, pois, deve, necessariamente, ser dotado de prévio poder coativo legítimo, na medida que goza de investidura no cargo como autoridade pública. Trata-se de uma garantia para o próprio 
jurisdicionado. A Declaração Universal dos Direitos Humanos (1948), um documento jurídico histórico da dignidade humana, assentou que todo homem tem direito a um julgamento justo e público por parte de uma jurisdiçáo independente e imparcial, para decidir seus direitos e seus deveres (COMPARATO, 1999, p. 211-218).

É interessante ainda notar que a Constituição da República Federativa do Brasil vigente incorporou a ideia do princípio do juízo natural em dois dispositivos, no seu Capítulo sobre os chamados direitos e garantias fundamentais. $\mathrm{O}$ texto constitucional deixa manifesto que não haverá juízo de exceção (art. $5^{\circ}, \mathrm{XXXVII),} \mathrm{bem} \mathrm{como} \mathrm{estabelece} \mathrm{que}$ ninguém será processado, nem julgado, senão por autoridade competente (art. $5^{\circ}$, LIII).

A inadmissibilidade de juízo de exceção é uma limitação da própria potestade estatal e, ao mesmo tempo, uma garantia ao cidadáo, que não poderá ser submetido a qualquer julgamento senão perante o juízo previamente estabelecido, com legítima autoridade pública, para apreciar e decidir a questão litigiosa.

No segundo artigo pergunta-se se é lícito ao juiz, baseado no que outros lhe expóem, julgar contra a verdade que conhece. São Tomás responde reafirmando que é função específica do juiz julgar "enquanto investido de autoridade pública". Por este motivo ele se informa "não pelo que sabe como pessoa privada, mas pelo que conhece como pessoa pública". Isso pode acontecer em geral e em particular: em geral "pelas leis públicas, divinas ou humanas": e, contra estas leis, náo pode ser admitida nenhuma prova. Mas, quando se trata de um caso particular, o juiz tem que basear-se não sobre o que sabe como pessoa privada, mas sobre "instrumentos, testemunhas e outros documentos legítimos". Porém, o que o juiz sabe, como pessoa privada, pode ser de ajuda para "discutir mais rigorosamente as provas aduzidas". Estas nunca podem ser repudiadas e precisam fundamentar o juízo.

É notável a preocupação tomasiana em analisar a licitude de o juiz jugar com base nos fatos e provas, em contraposição até mesmo à verdade que possa conhecer como pessoa privada.

No âmbito processual, fala-se em "prova judiciária", destinada à demonstração da veracidade de fatos. O tema das provas, justamente por estarem preordenadas a atestar a veracidade de algo, refere-se ao tema da verdade e dos limites do conhecimento humano. Fala-se de verdade material e verdade processual. A primeira é entendida como máxima correspondência entre a realidade fática e a sua reconstrução. A segunda diz respeito à provável correspondência com a realidade, caracterizada essa probabilidade lógica pela idoneidade das informaçóes levadas aos autos do processo.

Onde se busca a ordem jurídica justa, o certo é que não se admite que a decisão judicial não seja baseada em uma razoável cognição dos fatos e das provas produzidas. Contudo, a questáo é responder a uma pergunta básica: qual é a melhor teoria para fundamentar a convicção do julgador? 
Dois modelos básicos são propostos para enfrentar tal questionamento: o decisionista e o cognitivista. O primeiro baseia-se na busca de uma verdade absoluta, perscrutável sem limites e calçada em juízos valorativos orientados até mesmo por critérios predominantemente subjetivos do juiz, não raras vezes exclusivamente pessoais. Diz que sua pretensa legitimidade assenta-se na fonte da autoridade do julgador, bem como nos critérios de valor por ele adotados como fundamento da decisão, tais como, sabedoria, moralidade própria (FERRAJOLI 1995, p. 541). Note-se que Santo Tomás já falava desse critério decisionista pessoal, quando fazia menção à ciência da verdade que se tem como pessoa privada, e não como autoridade pública (AQUINO, 1980, p. 2568). O segundo lastreiase em uma verdade processual, a partir do conjunto probatório obtido mediante critérios os mais objetivos possíveis (FERRAJOLI, 1995, p. 541).

Agora, sabe-se que a arte do direito, há muito, afirma a chamada livre convicção do juiz. Acolhendo a filosofia prática aristotélica, São Tomás também reconhece que o juiz é o mediador real de todo o processo de aplicação da justiça particular corretiva: tanto assim que ao juiz, enquanto "justiça animada”, cabe a efetivação do que é justo na particularidade do caso, ao realizar o seu julgamento (BITTAR; ALMEIDA, 2010, p. 261-262).

Por tudo isso, compete ao juiz julgar a partir da máxima verdade que puder conhecer dos fatos. Contudo, não pode se afastar da objetividade das provas existentes. A sua ciência pessoal pode até ajudá-lo a avaliar, com maior critério, todo o acervo probatório a ser examinado, mas respeitados os limites objetivos dos elementos probatórios reunidos.

O terceiro artigo questiona "se o juiz pode julgar mesmo quem não tem acusador".

Na resposta, São Tomás cita um texto da Ética de Aristóteles, para quem "os homens buscam proteção junto do juiz, como se fosse a justiça viva”. O juiz, por sua vez, precisa decidir entre duas partes, a saber, o autor da acusação e o réu. Logo, quando falta o acusador, o juiz náo pode condenar. A esse respeito, ele cita um texto do livro dos Atos $(25,16)$, que faz referência à legislação dos Romanos. Estes não podiam condenar o acusado, na ausência dos acusadores; e também quando este não tinha a possibilidade de se defender dos crimes a ele imputados.

Como se vê, São Tomás, em plena medievalidade, preocupava-se com a questão de um julgamento sem a figura de um acusador, tanto que assim se posicionou: "O juiz não pode condenar quem não tem acusador”. (AQUINO, 1980, p. 2569).

Sua posição, pois, era franca e direta pela jurisdicionalidade em sentido estrito. A atitivade jurisdicional caracteriza-se pela convergência de princípios processuais voltados à garantia do indivíduo e ao acautelamento da correta atuação jurisdicional, tais como a separação orgânica das funções de acusar, defender e julgar, base do contraditório. Vedase o arbítrio do julgador. Ele fica adstrito ao material probatório trazido ao processo pela atividade dialética das partes (GOLDSCHMIDT, 1935, p. 113). 
O sistema acusatório, portanto, é tido como um imperativo garantista do moderno processo penal, haja vista que assegura a imparcialidade do julgador e a dignidade do próprio acusado, pilares de um Estado Democrático de Direito, que não se coaduna com qualquer espécie de abusos da prepotência estatal (LOPES JÚNIOR, 2006, p. 164-165).

O último artigo questiona se o juiz pode licitamente relaxar a pena”.

$\mathrm{Na}$ resposta ele explica, citando um texto anterior (art. II), que o juiz deve julgar entre o acusador e o réu; e, além disso, proferir a sentença judicial não como pessoa particular, mas investido de poder público. Há, pois duas razóes para ele não absolver da pena o réu. A primeira se refere ao acusador que, às vezes, foi vítima de uma injúria e tem direito a que o réu seja punido: e é papel do juiz dar a cada qual o seu direito.

A segunda razão diz respeito à república, em nome da qual ele exerce sua função e cujo bem exige que os malfeitores sejam punidos.

Em seguida, porém, ele distingue "os juízes inferiores" e o "supremo juiz, a saber, o príncipe a quem foi plenamente cometido o poder público". Este pode absolver o réu em duas circunstâncias: se aquele que sofre injúria perdoou; ou se a ele, príncipe, parecer que o relaxamento da pena não prejudica a utilidade pública.

Por fim esclarece que o juiz que remitisse a pena desordenadamente causaria dano à comunidade. Nesta é importante que sejam punidas as más açóes "para que se evitem os pecados”. Além disso, o juiz, relaxando a pena, causaria dano também à pessoa que sofre a injúria, pois a pena "de certo modo lhe restitui a honra". (AQUINO, 1980, p. 2571).

\section{A Injustiça Legal como Vício do Juiz que Julga, a partir do Pensamento de Habermas}

\subsection{Distinção do Paradigma de Habermas e Acesso à Questão da Pessoa Moral}

Vai ser analisado, agora, o tema da injustiça legal como vício do juiz que julga, a partir do pensamento de Habermas. Inicialmente é importante ter em mente a profunda diferença paradigmática com relação à abordagem de São Tomas. Deve-se entender que Sáo Tomas trabalha no plano da moral pessoal, enquanto Habermas pensa a questão a partir do paradigma procedimental.

Isso significa que Habermas não foca a abordagem do direito e da justiça na figura do juiz que julga, mas no procedimento do julgamento, que é situado num amplo horizonte de sua teoria do direito. Em seu livro Direito e Democracia essa ampla teoria é desenvolvida na tensão entre facticidade e validade, tendo uma abordagem tanto sociológica, como filosófico-moral. Uma das críticas que Habermas fez a Rawls e a Dworkin é justamente a de que suas teorias movem-se apenas no âmbito da filosofia moral. Comentando Rawls ele afirma: "O que é específico na validade do direito, a tensão entre facticidade e validade 
inerente ao próprio direito não entra em seu campo de visão" (HABERMAS, 1997a, p.92). A legitimidade do direito implica, além de uma teoria filosófica da justiça, seu acerto de contas com a sociologia do direito. Sob o foco da tensão entre facticidade e dialética, sociologia e filosofia, os sistemas dos direitos e a distinção entre normas morais e jurídicas, os princípios do Estado de Direito, a racionalidade da jurisdição e a legitimidade da jurisdição constitucional são os elementos essenciais de seu primeiro volume da edição em português (1997a). Enquanto o conceito procedimental da política deliberativa, o papel da sociedade civil e da esfera pública, bem como os paradigmas do direito constituem os elementos fundamentais de seu segundo volume (1997b).

Habermas trata de aprimorar os procedimentos para melhorar o julgamento. Mesmo assim a abordagem procedimental, não elimina a questão moral do juiz que julga, antes a mantém intacta dentro de uma abordagem mais ampla do direito. Ele mantém a ideia da sociedade como constituída de pessoas livres e iguais. Segundo seu próprio depoimento: "A esfera pública, entendida como espaço do trato comunicativo e racional entre as pessoas, é o tema que me persegue a vida toda." (2007, p. 19). A afirmação das pessoas e do trato racional entre elas é o ponto de partida para abordar a questão. Trata-se primeiro de entender como o autor compreende a pessoa para considerar, em seguida, a responsabilidade da pessoa do juiz em relação à decisão injusta. Essa esfera pública é um dos elementos constitutivos da pessoa para Habermas, como se pode verificar em sua passagem abaixo:

...o homem é um animal que, graças à sua inserção originária numa rede pública de relaçóes sociais, consegue desenvolver as competências que o transformam em uma pessoa. [...] nenhuma outra espécie [...] necessita de um período táo longo de educação no seio de uma família e de uma cultura pública compartilhada intersubjetivamente pelos semelhantes. [...] radical dependência de uns em relação aos outros. (2007, p.19-20).

Essa interdependência é constitutiva do ser humano, por esse motivo ele também afirma quanto à consciência que ela é privada apenas na aparência, pois: "continua a alimentar-se, [...], dos fluxos da rede cultural de pensamentos públicos, expressos de modo simbólico e compartilhados intersubjetivamente (2007, p. 21). Já desde Conhecimento e interesse Habermas, desenvolveu uma significativa crítica desfechada contra autores como Kant, Hegel, Marx, Comte, Pierce e Dilthey. Mediante a qual o autor reconhece a importância da filosofia transcendental e seu reconhecimento do acesso ao mundo como mediado pela faculdade humana da representação. Mas mostra a necessária crítica à abstração e ausência de historicidade de Kant a partir de Hegel, o qual mostra a historicidade das categorias ontológicas, expondo o desenvolvimento do espírito humano. Hegel por sua vez é criticado por Marx por não levar em conta as condiçôes materiais da produção como elemento condicionante da produção simbólica da auto-consciência. Desse modo desfecha dura crítica à pretensa neutralidade científica pretendida pelo positivismo. Com Pierce mostrou que: 
A pesquisa empírico-analítica é o prosseguimento sistemático de um processo cumulativo de aprendizagem, que se efetua de maneira pré-científica no círculo das ações instrumental. A pesquisa hermenêutica confere uma forma de método ao processo de entendimento (e de autoentendimento), o qual é aprendido de maneira pré-científica no contexto de tradiçôes próprio das interaçóes simbolicamente mediadas. (HABERMAS, 2014, p. 293).

Desde então ele entende que a gramática da linguagem corrente possui um valor posicional transcendental, "que regula os elementos não linguísticos de uma prática de vida exercida." (2014, p. 294). Neste contexto ele apresenta o significado de realidade nos seguintes termos: "A realidade se constitui no quadro de uma forma de vida de grupos comunicantes, organizada em linguagem corrente. Real é o que pode ser experimentado sob as interpretaçôes de uma simbólica vigente.” (2014, p. 294). É importante notar que a ideia de simbólica vigente não está de forma alguma presa à ideia cientificista. Ela se apresenta como expressão que envolve os vários discursos: teórico, prático, estético, terapêutico e explicativo, como se explicita na sua Teoria do agir comunicativo, no primeiro volume quando trata da racionalidade (HABERMAS, 2012a, p. 31 et seq.) e no segundo volume quando aborda o mundo da vida (2012b, p. 207 et seq.). Já em “conhecimento e interesse" Habermas procurou demonstrar que a produção teórica está vinculada a um fundo hermenêutico da ação no mundo mediado pela filosofia prática. Por esse motivo é facilmente compreensível a seguinte afirmação do autor:

Jamais consegui aceitar a idéia (sic) de que a autoconsciência constitui, por si mesma, um fenômeno originário. [...] Nos olhares de um "tu", [...], eu me torno consciente de mim mesmo, não somente como um sujeito capaz de vivenciar coisas em geral, mas também, e ao mesmo tempo, como um "eu" individual. Os olhares subjetivadores do outro possuem uma força individuadora. (2007, p. 21).

Fica clara a constituição intersubjetiva, da subjetividade da pessoa do juiz que julga. A pessoa do juiz participa de uma realidade mediada simbolicamente e experimentada nesta mediação. Para verificar a validade de seu julgamento é necessário compreender o direito no qual está inserido, por tanto toda a teoria do direito de Habermas indicada acima é constitutiva dessa análise.

\subsection{A Injustiça Legal como Vício do Juiz que Julga, por Ignorância Paradigmática do Direito}

Por isso em primeiro lugar, para compreender a questão da injustiça legal como vício do juiz que julga a partir do pensamento de Habermas é necessário partir do entendimento do Estado de Direito, médium constitutivo do direito legal. 
Neste sentido Habermas afirma na passagem que segue:

Os direitos fundamentais, apesar de serem determinados in abstrato, só são encontráveis em constituições históricas e sistemas políticos. Eles são interpretados e incorporados em ordens jurídicas concretas, através do direito constitucional ou da realidade constitucional das instituiçôes e processos políticos. (1997a, p. 241).

Como só se encontram os direitos fundamentais em constituiçóes históricas e sistemas políticos, fala-se aqui de ordens jurídicas concretas. Consequentemente a injustiça legal, aqui considerada, é atributo moral da pessoa de um juiz que julga injustamente dentro de uma ordem concreta. Como já foi esclarecido na passagem sobre São Tomas, a injustiça como vício supóe a consciência em sentido essencial, porém ela pode ser cometida em sentido acidental por ignorância do direito ou por ignorância do fato. Como foi visto, a ignorância do fato quando invencível pode ser tolerada no contexto do direito romano, mas não a ignorância da lei. $\mathrm{O}$ que vai ser apurado aqui, enquanto vício do juiz que julga, segundo o pensamento de Habermas, diz respeito náo à invencível ignorância de fato, mas à ignorância do direito, produzida pela cegueira paradigmática do juiz. É importante notar que a ignorância do direito, não corresponde apenas à ignorância da lei. A questão da ignorância do direito diz respeito também à ignorância da necessária reconstrução dos princípios do direito, para a execução do julgamento justo. Ignorância essa que pode tornar-se um ato voluntário do juiz que se recusa a atualizar-se quanto aos paradigmas do direito. Entende-se que tal perspectiva pode tornar-se um vício, que provoca a injustiça no julgamento do juiz. Tal perspectiva deve ser abordada a partir de sua Teoria do Direito que se manifesta da seguinte maneira:

Ao contrário da filosofia, a teoria do direito náo pode desprezar os aspectos resultantes do nexo interno entre direito e poder político, principalmente a questão da permissão jurídica para o emprego da força legítima por parte do Estado. [...] A teoria do direito abrange não somente a legislação e a administração, [...] mas também o sistema jurídico, em sentido mais amplo. Ela se distingue da dogmática jurídica através da pretensão de produzir uma teoria da ordem jurídica em sua totalidade. E nisso, ela leva em conta as perspectivas dos outros participantes, ao introduzir na própria perspectiva de esclarecimento, que é a do jurista especializado, os papéis do legislador político, da administração e dos membros do direito (...). (HABERMAS,1997a, p. 244).

Consciente de que o juiz não pode decidir sem uma jurisdição que corresponda a sua decisão, cumpre também entender que para não ser injusta a decisão deve também basearse na melhor racionalidade. Neste sentido ele examina os vários paradigmas. Começando com a hermenêutica afirma: "A hermenêutica tem uma posição própria no âmbito da 
teoria do direito, porque ela resolve o problema da racionalidade da jurisprudência através da inserção contextualista da razão no contexto histórico da tradição.” (1997a, p. 248). Consequentemente constitui um vício ignorar a inserção da razão no contexto histórico da tradição. Por outro lado constitui um outro vício apegar-se acriticamente aos preconceitos.

Quanto ao realismo, Habermas afirma: "Na medida em que o resultado de um processo judicial pode ser explicado pelos interesses, [...] a prática de decisão não é mais determinada internamente através da seletividade de procedimentos, do caso e do fundamento do direito." (1997a, p. 249). Porém logo adiante sentencia: “Os realistas não conseguem explicar como é possível combinar a capacidade funcional do sistema jurídico com a consciência dos especialistas participantes, a qual é radicalmente cética em termos de direito." (1997a, p. 250).

Igualmente dois erros opostos advêm dessa perspectiva náo levar em conta a influência dos interesses nas decisóes judiciais, por um lado, e negar a capacidade funcional do sistema jurídico de tomar decisóes racionais consistentes, por outro.

Em relação ao positivismo jurídico Habermas faz as seguintes colocações: "O positivismo jurídico pretende, ao contrário fazer jus à função da estabilizaçáo de expectativas, sem ser obrigado a apoia a legitimidade da decisão jurídica na autoridade impugnável de tradiçóes éticas." (1997a, p. 250). E complementa em seguida: "Essa legitimação através da legalidade do procedimento da normalização privilegia a procedência, ou melhor, o processo correto da positivação ou da resolução em detrimento da fundamentação racional do conteúdo de uma norma. (1997a, p. 250).

Aqui, por um lado a capacidade funcional do sistema jurídico é superestimada, desembocando numa posição decisionista, por outro lado nega-se a influência dos interesses e o contexto da tradição.

Dworkin procura elaborar uma teoria da decisão correta, capaz de superar os erros das três teorias precedentes. Neste sentido, assim se expressa Habermas:

Contra o realismo, Dworkin sustenta a possibilidade e a necessidade de decisões consistentes ligadas a regras, as quais garantem uma medida suficiente de garantia do direito. Contra o positivismo, ele afirma a possibilidade e a necessidade de decisôes "corretas", cujo conteúdo é legitimado à luz de princípios (e não apenas formalmente através de procedimentos). No entanto, a referência hermenêutica a uma pré-compreensão determinada por princípios náo deve entregar o juiz à história de tradiçóes autoritárias com o conteúdo normativo, ao contrário obriga-o a uma apropriação critica de uma história institucional do direito, na qual a razão prática deixou seus vestígios. (1997a, p. 252).

Como se pode observar, introduziu-se nesta passagem a questão dos princípios, que legitimam decisóes "corretas" contra o formalismo positivista, porém vinculados a uma 
apropriação crítica para defender-se de tradiçôes autoritárias. Segundo Habermas, para Dworkin:

[...] o próprio direito vigente já incorporou conteúdos teleológicos e princípios morais, assimilando os argumentos da decisão do legislador político. [...] Todavia, na prática da decisão judicial, os argumentos de princípio gozam de primazia em relação aos argumentos de determinação de finalidade: (1997a, p. 257-258).

Como se pode ver, uma vez que se entende que os conteúdos teleológicos e de princípios morais já foram incorporados ao direito, a prática da decisão não precisa mais ficar preza ao formalismo legal, como no positivismo, mas pode incorporar argumentos de princípios e de finalidade. No conflito entre princípios ele lembra que: "Um princípio passa à frente do outro conforme o caso a ser decidido. No desenrolar dos casos, estabelece-se entre os princípios uma ordem transitiva, sem que isso arranhe sua validade.” (1997a, p. 259). A escolha entre princípios é feita a partir de critérios de análises racionais mantendo sua indisponibilidade orientada para as "únicas decisóes corretas". Habermas entende que a escolha do paradigma não é arbitrária, uma vez que depende de uma situação hermenêutica inicial que não está a nossa disposição. Entendemos que se trata das condiçóes pré-reflexivas, as quais porém são compartilhadas pelos membros da comunidade jurídica. Porém ele entende que a pré-compreensão pragmática não é incorrigível, uma vez que é testada e modificada no decorrer do próprio processo de interpretação. (1997a, p. 260). Embora o mundo da vida forme o contexto de fundo pré-reflexivo, ele pode ser parcialmente tematizado e discutido.

A questão que se coloca é: "De que modo a prática da decisão judicial pode satisfazer simultaneamente, ao princípio da segurança e da pretensão de legitimidade do direito?” (1997a, p. 261). Conciliar segurança e legitimidade não é tarefa fácil ao direito, porém trata-se de uma questáo fundamental para diferenciar o juízo justo e o juízo injusto. Habermas lembra que os realistas tinham abalado três dogmas da teoria do direito: a suposição de que existem direitos; de que os casos atuais podem ser decididos consistentemente conforme o direito vigente e que os juízos dos tribunais são racionais. Um pouco adiante afirma: "Dworkin torna possível interpretar essas três suposiçóes de um modo construtivo menos vulnerável. Os direitos indisponíveis manifestam um sentido deontológico, porque eles formam um peso maior do que os bens coletivos e determinaçóes de objetivos políticos." (1997a, p. 265). Dworkin compreende que o direito é composto por regras e princípios. Ele entende princípios como "conjunto de padróes que não são regras, que devem ser observados porque é uma exigência de justiça, equidade ou alguma outra dimensão da moralidade." (DWORKIN, 2007a, p. 36). Para ele "a interpretação jurídica é uma leitura principiológica" (2007b, p. 478): sua finalidade é colocar o princípio acima da prática para mostrar o melhor caminho para um futuro melhor (2007b, p. 492). Desse 
modo afirma: "Os juízes que aceitam o ideal da integridade decidem casos difíceis tentando encontrar, em algum conjunto de princípios sobre os direitos e deveres das pessoas, a melhor interpretação da estrutura política e da doutrina jurídica de sua comunidade." (2007b, p. 305).

É possível por tanto uma reconstrução do direito e sua afirmação do princípio de integridade nos seguintes termos:

O princípio de integridade caracteriza o ideal político de uma comunidade, na qual os parceiros associados do direito se reconhecem reciprocamente como livres e iguais. [...] É um princípio que obriga [...] a realizar a norma básica da igual consideração e do igual respeito por cada um nas práticas e instituiçóes da sociedade: [...] os cidadáos reconhecem mutuamente um sistema de direitos, o qual lhes garante autonomia privada e pública. (1997a, p. 267).

Segundo Habermas, para os críticos Dworkin atribui ao seu Hércules um programa irrealizável. Cabe ao juiz a igual consideração e o igual respeito por cada um em suas práticas decisórias. Mas essa não é uma tarefa fácil para o juiz conforme lembra Günter: "Se toda norma válida depende de uma complementação coerente através de todas as outras, numa situação de normas aplicáveis, então o seu significado se modifica em cada situação." (GÜNTER apud HABERMAS 1997a p. 272). Porém, Habemas lembra logo em seguida que: "A complexidade dessa tarefa é de fato reduzida através da compreensão jurídica paradigmática que prevalece num determinado contexto". A entrada dos paradigmas que prevalecem implica uma posição análoga à invencível ignorância. Pois não se pode vencer a cegueira de nosso provincialismo histórico. Não se pode exigir de um juiz mais que a reconstrução do direito mediante o melhor paradigma disponível. Porém essa limitação, pelo que já foi visto, não pode ser considerada propriamente um vício da justiça. No caso específico do juiz, não pode ser considerada um vício do mesmo, por ser uma limitação inevitável da condição humana.

Dadas essas ressalvas, manifesta-se o caráter pragmático e procedimentalista da teoria de Habermas. Partindo da seguinte afirmação: "Ao contrário da exigida coerência ideal do direito vigente, as interpretaçóes de caso coerentes permanecem, em princípio, indeterminadas no interior de um paradigma jurídico fixo" [...] (1997a p. 276). E continua mais adiante: "Isso já é uma razão suficiente para que uma compreensão procedimentalista do direito delineie um nível no qual os paradigmas jurídicos, agora reflexivos, se abrem uns aos outros e se comprovem na pluralidade de interpretaçôes”. (1997a, p. 276). Embora a cegueira paradigmática seja uma limitação inevitável, a assunção dos paradigmas ao nível reflexivo e o diálogo entre eles tornam-se virtudes intelectuais importantes daqueles que julgam. Consequentemente a ignorância consciente e proposital de tal diálogo, que é condição da escolha das melhores razões, torna-se também um vício, que produzirá o juízo injusto do juiz que poderia ser evitado. 
Segundo Habermas, é necessário ancorar as ideias da teoria do direito "no ideal político de uma 'sociedade aberta dos interpretes da constituição', ao invés de apoiá-las no ideal da personalidade de um juiz". (1997a p. 278). Embora seja objeto desta pesquisa investigar a injustiça legal como vício do juiz que julga, é necessário entender que nosso autor se move num paradigma intersubjetivo, neste contexto: "O princípio monológico torna-se especialmente insustentável, quando se tem como necessários paradigmas jurídicos redutores de complexidade, como é o caso de Günter”. (1997a p. 278). É necessário entender que o juiz decide e julga, porém não com base apenas numa consciência isolada em si mesma, mas como membro de uma comunidade jurídica e de uma sociedade. Nas palavras de Habermas: "Hercules poderia imaginar-se como parte de uma comunidade de interpretação de especialistas em direito e, neste caso, teria que orientar suas interpretaçóes pelos standards da prática de interpretação reconhecidos na profissão: [...]”. (1997a, p. 279). Nessa perspectiva ele propóe uma "reconstrução da prática de interpretação pelo caminho de uma teoria do direito, e não uma dogmática do direito”. (1997a, p. 280). O que o afasta do positivismo. Aqui pode-se pensar um vício no juiz "Hercules" que julga a partir de si, desconsiderando a pertença à comunidade jurídica e sua dimensão constitutiva intersubjetiva. Ele, ao reconstruir o direito, não pode desprezar os padróes de interpretação vigentes. A decisão correta do juiz exige a conformidade de sua reconstrução do direito e aquilo que pode ser aceito pela comunidade jurídica. Exige, portanto, o domínio dos paradigmas teóricos disponíveis para a interpretação e a competência para aplicá-los adequadamente numa decisão que pode ser aceita pela comunidade jurídica. $\mathrm{O}$ juiz não pode por simples "orgulho" colocar-se acima da comunidade jurídica, não lhe apresentando bons argumentos, capazes de sustentar perante ela sua decisão. Ou ainda por "preguiça mental", desconhecer os paradigmas hermenêuticos disponíveis necessários à abordagem do caso que decide. Podemos chamar esse vício de vício da decisão solipsista do Juíz. O juiz não decide apenas para si e sua consciência, quando decide o faz como participante de uma comunidade que é parte da constituição de sua própria consciência e à qual presta contas. A qual inclusive pode revisar sua decisão.

Essa compreensão vem somar-se à tese de São Tomas a respeito da questão "se é lícito ao juiz, baseado no que lhes expóem, julgar contra a verdade que conhece". A compreensão do juiz como membro da comunidade jurídica fornece a clareza de que ele não decide para si, mas para a comunidade. Neste sentido só pode levar em conta o que pode sustentar com bons argumentos perante a mesma. Suas convicçóes pessoais passam ao segundo plano.

\subsection{A Superação do Solipsismo Metódico a partir da Filosofia de Apel e a Per- tença do Juiz a Comunidade}

A questão do solipsismo metódico, desenvolvida no livro "Estudos de moral moderna”, por Karl Otto Apel, companheiro de Habermas na ética do discurso, emerge bastante 
esclarecedora da posição que é assumida por ambos. Por isso, haverá dela, a seguir, breve apresentação, pois essa questão possibilita a transição da lógica da argumentação em direção da ética. é, a superação do solipsismo metódico (1994, p. 15 et seq.).

É importante entendermos que Habermas e Apel navegam no contexto da guinada linguística. Por isso, vai ser introduzida a questão da guinada linguística para tornar mais clara e adequada a questão da superação do solipsismo metódico. Neste contexto "...a linguagem mediatiza todo sentido e validade”. (HERRERO, p. 12). Nessa perspectiva, Wolfgang Kuhlmann comenta "que nós com pensamentos sobre algo já sempre somos referidos reciprocamente uns aos outros, a uma esfera pública”. (p. 41). Assim, Apel parte de Peirce, mediante o qual é na tríplice relação semiótica que se dá a constituição do sentido de algo do mundo, como algo significativo que tem que ser interpretado. A língua natural pressupóe identidade dos significados, o que remete para um mundo da vida e para uma comunidade real de língua, na qual já existe um entendimento intersubjetivo que possibilita a compreensão do mundo compartilhado por todos. Neste sentido, a linguagem natural é, no seu uso atual, condição transcendental de possibilidade de todo sentido e validade (HERRERO, p. 11-12). Toda proposição semântica da língua natural é implicitamente pragmática (p. 13). Khulmann mostra que: “...o mero opinar que meus pensamentos ou convicçóes são privados, cai numa auto-contradição performativa." (p. 47): isso porque o opinar já implica uma jogada num jogo que teve início e possui regras. O opinar só é possível no interior de um jogo de linguagem constituído numa comunidade de comunicação.

Desse modo, como afirma Herrero:

[...] o "logos" da linguagem natural só pode ser adequadamente definido por ambos os significados: o performativo e o proposicional em unidade. E, portanto, que (sic) entre esses dois planos terá que haver sempre uma coerência, que pode ser designada como a consistência do "logos" humano. (p. 14).

Desse ponto de vista da interpretação pragmática-hermenêutica da linguagem, pode ser acompanhada melhor a proposta de superação do solipsismo metódico elaborada por Apel. Inicialmente, o autor coloca as condiçóes de possibilidade da ciência na passagem da certeza a argumento, no reconhecimento do valor transcendental da linguagem e da ilimitada comunidade crítica de comunicação, como pressuposto a se realizar, construído de maneira empírica e normativo-crítica. Como juízos de valor decorrem do horizonte significativo que possibilita a experiência, a ciência analítica deve reconhecer os pressupostos teóricos de valor, de relevância intersubjetiva, para a auto-experiência histórica. A distinção de juízos de fato e de valor já pressupóe uma ética mínima que implica num engajamento como condição de possibilidade da formação do consenso (APEL 1994, p. 15 et seq.). Retoma, então, a questão do solipsismo, abordando-o conforme os passos 
a seguir: primeiramente, coloca que o solipsismo metódico está em contradição com a intersubjetividade da analítica da linguagem e que os pressupostos da ciência unitária estão em contradição com os pressupostos da semântica construtiva. Em segundo lugar, demonstra que o solipsismo, como pressuposto da linguagem unitária, é um puro realismo que nega o pressuposto pragmático transcendental. Finalmente, em terceiro lugar, propóe a superação do solipsismo metódico, pela reinterpretaçáo do pressuposto das convençóes, que supera a ciência unitária a partir da afirmação do entender em ciências sociais, como "continuum" com a problemática da compreensão meta-científica, pela ampliação do sentido de racionalidade humana (APEL, 1994, p. 31).

Porém, como afirma o autor, "a ética pressuposta pela lógica como condição da sua possibilidade implica a obrigação de que a lógica e a ciência sejam aplicadas". (APEL, 2000, p. 456). E continua, logo a seguir: "a ética da argumentação, que transforma lógica e ciência em obrigação, só é pressuposta de maneira inalienável, quando queremos a argumentação lógica." (p. 456). Assim mostra a estrutura condicional de ciência lógica e ética, concernente a comunidade de comunicação. Portanto, se esclarece melhor a ética pressuposta na comunidade crítica de comunicação e na ciência em geral.

A tese da pressuposição da ética pela lógica leva à restrição do círculo, pois toda a fundamentação já pressupóe a validação da lógica (APEL, 2000, p. 458). Porém, Apel, apoiando-se em Morris, afirma que a função semântica dos signos pressupóe um "interpretante” e, portanto, a tese do círculo ignora a dimensão pragmática (2000, p. 461).

Por outro lado, apóia-se em H. Lenk, que mostra que algumas partes da lógica não podem ser rejeitadas, sem que as reivindique durante a própria crítica. Trata-se da lógica das consequências que perfazem os componentes da lógica, não revogáveis por meio da crítica racional (APEL, 2000, p. 454). A abordagem de Apel entende-se como "uma transformaçáo senso-crítica da filosofia transcendental, que tem no factum apriorístico da argumentação um ponto de partida quase-cartesiano iniludível”. (2000, p. 465). Assim, todos que com o pensamento filosófico prometem respostas as suas questóes já reconhecem as regras do jogo válidas para a criticist frame. (2000, p. 467). Diferente de Popper, para Apel a escolha da "criticist frame" é a única decisão semântico-pragmaticamente consistente no sentido do jogo de linguagem que teve início (2000, p. 467).

Apel lança mão da radicalização transcendental filosófica de Wittgenstein, que já pressupóe implicitamente as condiçôes lógicas e morais da comunicação crítica (2000, p.468). Assim, supera a restrição formulada com base na distinção de Hume:

... a crítica de sentido transcendental pode demonstrar em primeiro lugar que a aceitação das regras do jogo de uma comunidade crítica de comunicação não é um factum empírico, senão que ele pertence às condiçóes de possibilidade de validade da constatação empírico-científica de fatos. 
Além disso, como já se evidenciou, o reconhecimento de uma norma moral básica inclui-se entre as condiçôes de possibilidade de todo auto-entendimento válido. (2000, p. 469-470).

Portanto, segundo Apel, a participação na práxis comunicativa implica a participação numa discussão virtual e a corroboração da própria participação no jogo de linguagem transcendental da comunidade comunicacional transcendental (2000, p. 476).

A comunidade de argumentaçáo não é idêntica à comunidade dos cientistas. No $a$ priori da argumentação reside o anseio de se justificar não apenas as 'asserções' da ciência, mas, além disso, todos os anseios humanos que se podem justificar por meio de argumentos racionais (APEL, 2000. p. 479-480).

Herrero, entende que:

...o discurso é a forma pública reflexivamente intransponível de todo pensar, porque ele representa a instância última filosófica, científica ou política na qual e diante da qual tem que justificar-se a responsabilidade comum dos homens pelo seu próprio pensar e pelo seu próprio agir, [...] por todas as pretensôes possíveis que possam ser levantadas no mundo da vida. Nenhuma fundamentação da ética, da semântica ou da pragmática, da racionalidade lógico-matemática ou de qualquer outra racionalidade, é possível sem passar pela mediação do discurso e pelo discurso entendido em toda sua radicalidade, i.é, contudo o que ele implica. Neste sentido o discurso é metodicamente intranscendível. (p.14).

Como pode ser confirmado, na leitura de Herrero, o discurso também é intranscendível e instância filosófica última diante da qual a responsabilidade dos homens tem que justificar-se. ${ }^{1}$

Abre-se assim o espaço para uma ética com conteúdo cognitivo, porém: “...a subjetividade da imposição egoísta de interesses precisa ser sacrificada, em prol de uma 'transubjetividade' da representação argumentativa de interesses”. (APEL, 2000, p. 480). Portanto, como se pode ver, para Apel:

O sentido da argumentação moral poderia ser expresso diretamente no princípio [...] de que todas as carências virtuais - devem se transformar em uma aspiração da comunidade de comunicação, de modo que sejam conciliáveis com as carências de todos os demais, pela via da argumentação. (Apel 2000, p. 480-481).

1 Há uma diferença significativa aqui com relaçáo ao pensamento de Habermas que fica destacada com esse comentário. Para Herrero, o discurso é a única fundamentação possível e única forma pública de todo o pensar que deve ser entendido em toda a sua radicalidade. Essa ideia de discurso entendido em sua totalidade como única fundamentação, implica uma monologia que conflita com o pensamento de Habermas. Pois, ele reconhece nosso provincialismo histórico e mantém aberta uma reserva falibilista à outras possibilidades de pensar. 
Assim, o princípio fundamental da ética da comunicação é fundamento de uma ética da formação democrática da vontade por meio do consenso. Mas, só aquele consenso cujo fim seja a formação solidária da vontade. Esta fundamentação precisa ser posta em uma situação histórica concreta, que é determinada pelo conflito de interesses.

A pessoa que argumenta já pressupõe a comunidade ideal na comunidade real, embora saiba que a comunidade real está muito longe de se equiparar à comunidade ideal de comunicação. Mas a argumentação não tem outra escolha. (APEL, 2000, p. 487).

Daqui decorrem dois princípios, quais sejam: garantir a sobrevivência da comunidade real de comunicação, e a realização da comunidade ideal na real. Quem pensa efetivamente precisa fundamentar seu engajamento social.

$\mathrm{Na}$ era da ciência, a estratégia de emancipação deve servir-se do instrumental científico, das ciências histórico-hermêuticas do acordo mútuo.

Essas disciplinas $[\ldots]$ adquirem seu princípio regulador no sentido metodológico e ético normativo de uma fundamentação não subjetiva aleatória de juízos de valor, através do postulado da realização da comunidade ideal de comunicação. (APEL, 2000, p. 490).

Mediante articulação reflexiva da dimensão pragmática, Apel apresenta a escolha das regras da "criticist frame" como a única decisão, semântico-pragmaticamente consistente, no sentido do jogo de linguagem da argumentação. A aceitação das regras da comunidade científica é condição de validade da constatação empírico-científica de fatos e a comunidade de argumentação é mais ampla que a comunidade científica. E como pretende mostrar o comentário de Herrero, apresentado anteriormente, é também a única possibilidade coerente de fundamentação, que abrange as afirmações da ciência empírica, a matemática, a ética e a política e por conseguinte o direito.

Uma vez demonstrada a necessária pertença daquele que argumenta à comunidade de argumentação trata-se também do reconhecimento do sentido pragmático do argumento e da pertença do juiz à comunidade jurídica, que por sua vez pertence a uma comunidade e sociedade histórica e geograficamente situadas.

\subsection{A Questão dos Discursos de Aplicação, o Juiz, a Ponderação e o Procedi- mento}

Nesta parte final vai ser apresentada a posição de Habermas referente aos discursos de aplicação do direito. Já se compreendeu que nenhum juiz pode furtar-se à condição transcendental de membro participante de uma comunidade jurídica preconstituida, que verifica a validade de suas sentenças. 
Neste sentido:

A fresta de racionalidade que surge entre a força meramente plausibilizadora de um único argumento substâncial ou de uma sequencia incompleta de argumentos, de um lado, e a incondicionalidade da pretensão à "única decisão correta", de outro lado, é fechada idealiter através do procedimento argumentativo da busca cooperativa da verdade. (HABERMAS, 1997a, p. 283).

Habermas sabe que nos discursos de aplicação entram em jogo os interesses das partes imediatamente envolvidas. Além disso: “[...] entram interpretaçóes da situação, que dependem da autocompreensão e da compreensão diferencial do mundo do autor do delito e dos atingidos.”(1997a, p. 284). Habermas aceita a compreensão deontológica do direito de Dworkin, mas o faz seguindo as consideraçóes da teoria da argumentação admitindo as seguintes teses:

Em primeiro lugar, o discurso jurídico não pode mover-se auto-suficientemente num universo hermeneuticamente fechado do direito vigente: precisa manter-se aberto a argumentos de outras procedências [...] pragmáticos, éticos morais [...]. Em segundo lugar, a correção de decisóes judiciais mede-se pelo preenchimento de condições comunicativas da argumentação, que tornam possível uma formaçáo imparcial do juízo. (1997a, p. 287).

Ele reporta, porém, às objeções levantadas contra a tese de Alexy. A primeira referente às limitaçóes do agir forense que leva em conta os interesses das partes com suas práticas orientadas ao sucesso. Apesar disso, afirma que todos os participantes do processo, por mais diferentes que sejam seus motivos, fornecem contribuiçóes para um discurso, o qual serve, na perspectiva do juiz, para a formação imparcial do juízo (1997a, p. 288). A segunda diz respeito à indeterminação do processo do discurso. Quanto a essa objeção, Habermas entende que: "[...] Alexy teria que mostrar que esses princípios processuais e máximas de interpretação -[...] - apenas especificam as condiçôes gerais do processo de discursos prático-morais em relação à ligação com o direito vigente." (1997a, p. 288). A terceira entende que a racionalidade da decisão jurídica da decisão depende da racionalidade da legislação: o que nem sempre é o caso. Diante desta objeção, Habermas afirma: "Para fugirmos a essa objeção, precisamos enfrentar com Dworkin, a tarefa de uma reconstrução racional do direito vigente" (1997a, p. 289). A última objeção diz respeito à questâo da coerência que com Günter assume um conceito normativo: “[...] $\mathrm{O}$ “julgamento adequado' extrai sua correção da validade pressuposta das normas estabelecidas pelo legislador público”. (1997a, p. 289-290). Neste sentido compreendemos que numa "teoria procedimental, a legitimidade de normas jurídicas mede-se pela racionalidade do processo democrático da legislaçáo política”. (1997a, p. 290). Robert Alexy afirma: 
Habermas tem razão quando diz que a autonomia privada é um pressuposto necessário ao exercício da autonomia pública, sendo também acertado que "uma percepção adequada da autonomia pública serve como garantia da emergência da privada”. (2009, p. 137). Porém, ele continua mais adiante. "Mas como fim em si mesma, a autonomia privada pode colidir com a pública no 'mundo que nós conhecemos' e esta colisão é de dois princípios, a qual só pode ser solucionada pela ponderação e não através de uma redução, [...] de um princípio ao outro" (2009, p. 137-138). Habermas resolveu a questão em princípio, no atacado, mas não no varejo. Ela a resolveu do ponto de vista do legislador, mas náo do ponto de vista do juiz que julga cada caso particular. É por isso que Alexy afirma:

Isso significa que o paradigma procedimental pode fornecer à anunciada "ordem transitiva"? A resposta é sim e não. A mencionada "suposição de legitimidade da liberdade de discurso" pode ser interpretada como uma prerogativa prima facie. [...] Contudo prerrogativas prima facie não conduzem a ordens transitivas estritas. Quando os motivos contrários são mais fortes, elas podem ser afastadas. [...]. (2009, p. 138-139).

Alexy lembra que Habermas fala de outra luz, para o problema:

Qual solução nesta outra luz deve ser considerada a correta, depende do peso dos respectivos motivos correspondentes. Estes se referem tanto à autonomia privada quanto à autonomia pública e por fim é apenas em um discurso que se pode decidir a qual deve ser concedida a prerrogativa no caso de uma colisão. (2009, p. 139).

Que discurso será esse? Alexy responde entendendo como Habermas que o sistema de direitos deve assegurar a autonomia privada e pública de parceiros do direito. Por isso afirma: "O conteúdo da tensão entre legitimidade e a positividade do direito é controlado na jurisdição como um problema de decisão correta e, ao mesmo tempo, consistente". (2009, p. 292). Por tanto compete à decisão da pessoa do juiz, embasada na ponderação de argumentos. Como foi visto com Alexy, a autonomia privada, embora seja cooriginária com a autonomia púbica, pode colidir com ela. Neste contexto, segundo Habermas:

A finalidade dos meios jurídicos consiste inicialmente em conseguir decisôes corretas e, por isso, justas, no interesse das partes, através da revisão das decisóes promulgadas. A simples possibilidade da revisão obriga, além disso, os tribunais a uma fundamentação cuidadosa. (1997a, p. 294).

Neste caso o juiz pode incorrer na injustiça particular, por decidir um caso sem respeitar a coerência da ordem jurídica como um todo. "O tribunal tem que decidir cada caso particular, mantendo a coerência da ordem jurídica em seu todo.” (1997a, p. 295). O sistema prevê essa condição finita e falível do juiz. A decisão que precisa ser revista é uma decisão injusta. Como visto, confirma-se a pertença do juiz a uma comunidade 
jurídica, para não ter sua decisão revista, ele precisa transformar suas convicçóes pessoais em bons argumentos ou não levá-las em conta. Em São Tomás viu-se que essa decisão poderia ser injusta por ignorância do fato ou por ignorância da lei. No caso, acrescenta-se uma terceira por uma reconstrução equivocada do direito. Trata-se de uma derivação da ignorânica da lei, que não pode ser reduzida a ignorância da lei propriamente dita, pois o sistema jurídico, reconstruído em seus princípios não se reduz à letra da lei. A reconstrução correta depende da capacidade de lidar com os paradigmas jurídicos disponíveis e aplicá-los ao caso concreto num discurso coerente e consistente. Constitui vício do juiz que julga a acomodação ou apego sistemático e não reflexivo a um paradigma, que leva a sucessivas revisóes de suas decisóes. Pois neste caso ignora sua pertença a uma comunidade jurídica. Seu erro, aparentemente involuntário, deriva de um mau habito de não querer aprender, mediante o qual assume o risco voluntário de errar. Neste sentido o permanente estudo da doutrina apresenta-se como virtude necessária ao bom juiz, tendo na ignorância paradigmática seu vício oposto. Não é vício do juiz o erro eventual ocorrido numa reconstrução equivocada dos princípios do direito. Também não o é o erro paradigmático endossado pela comunidade jurídica que com ele venha a partilhar de uma mesma cegueira paradigmática em sua limitada visão de mundo, no tempo.

\section{Conclusões}

Foram apresentadas inicialmente duas questóes de São Tomas de Aquino, "a injustiça como vício" e "a injustiça do juiz que julga”. Verificou-se aí que nem toda injustiça corresponde a um vício, visto que para sê-lo ela precisa ser consciente, intencional e recorrente. Reconheceu-se a injustiça como ilegalidade enquanto vício especial, como todas as ilegalidades como vício geral e como desigualdade enquanto um vício particular. Viu-se que praticar atos injustos é próprio do injusto e que do ponto de vista moral não se pode sofrer injustiça voluntariamente, nem praticá-la involuntariamente.

Quanto à injustiça do juiz que julga, São Tomás recusa o julgamento de que não depende de nós, o que corresponde à impossibilidade de julgar quem está fora da sua jurisdição. E ele também apresenta a questão se é lícito ao juiz, baseado no que lhes expóem, julgar contra a verdade que conhece, mostrando já em seu tempo que o juiz não julga para si, mas para a comunidade, tendo que levar em conta o que lhe é apresentado. Apresenta também a questão da condenação de quem não é acusado: uma questão que hoje se manifesta no sentido de que a justiça só reage se for provocada. Finalizando com a questão do relaxamento da pena, Sáo Tomás deixa claro que o juiz não pode por conta própria diminuir a pena pois representaria dano à comunidade e a quem sofreu a injúria. Nestas colocaçóes já se expressa o sentido de pertença do juiz a uma comunidade.

Passou-se, na segunda parte do estudo, a abordar a questão da "injustiça legal como vício do juiz que julga, a partir do pensamento de Habermas”. Iniciou-se a abordagem 
distinguindo o paradigma procedimental do pensamento de Habermas, mostrando que a questão moral permanece intacta, fundada na pessoa moral. Esta desenvolve-se dentro de uma comunidade mediante a qual adquire as capacidades que a tornam pessoa moralmente responsável por seus atos. Compreende-se assim que a pessoa do juiz participa de uma realidade mediada simbolicamente e experimentada nesta mediaçáo, a qual é medida da imputação de sua responsabilidade moral.

Abordou-se, então, a injustiça legal como vício do juiz que julga, por ignorância paradigmática do direito. Inicialmente viu-se que a abordagem da questão implica a compreensão do Direito em sua tensão entre facticidade e validade, dada nas abordagens objetivas e normativas do direito, com suas mediaçôes sociológicas e filosóficas, passando por uma reconstrução dos princípios do sistema dos direitos modernos, seu vínculo entre direitos humanos e democracia, liberdades públicas e privadas, distintas da moral. Viuse como o Direito supóe o Estado, a política e o poder comunicativo e os subsistemas funcionais.

Só então pode ser situada a racionalidade da jurisdição abordando os paradigmas da Hermenêutica, do realismo, do positivismo e de Dworkin. Apresentou-se, a partir de Habermas, um novo tipo de injustiça legal, praticada pelo juiz que julga, como ignorância não da lei, mas do direito por cegueira inerente ao enrijecimento paradigmático. Apresentou-se o vício de ignorar a inserção da razão no contexto histórico da tradição e o de apegar-se acriticamente aos preconceitos. Outro vício identificado foi o de náo levar em conta a influência dos interesses nas decisóes judiciais, por um lado, e negar a capacidade funcional do sistema jurídico de tomar decisóes racionais consistentes por outro. Também pode ocorrer que se superestime a capacidade funcional do sistema jurídico desembocando numa posição decisionista.

Verificou-se nas limitaçóes do juiz "Hercules" em reconstruir a integridade do direito, um tipo de erro que não constitui vício da pessoa do juiz por tratar-se de matéria inerente à ignorância de fato. Trata-se de matéria inerente à finitude humana.

Abordou-se, então, o vício do solipsismo metódico do juiz, expondo a argumentação de Karl Otto Apel, que mostra o necessário enraizamento do saber teórico em regras práticas da comunidade de comunicação, a qual se constitui como o horizonte pragmático transcendental de qualquer argumentação em geral e da argumentação jurídica em especial.

Por fim, na questão dos discursos de aplicação, mostrou-se com Habermas que os erros dos juízes na reconstrução do direito podem parcialmente ter correção no procedimento jurídico de instâncias do direito que corrigem as decisóes inferiores terminando em decisóes colegiadas onde colocam-se as melhores condiçóes, embora finitas, para a reconstrução da integridade do direito. Com Alexy viu-se que os conflitos entre princípios, 
resolvidos no atacado, precisam ser tratados nas decisóes dos tribunais mediante a construção coletiva e argumentativa de discursos de aplicação através da ponderação.

\section{Referências}

ALEXY, Robert Os direitos fundamentais e a Democracia no Paradigma Procedimental do Direito de Jürgen Habermas. In: FRANKENBER, Günter; MOREIRA, Luiz. Jürgen Habermas, 80 anos. Rio de Janeiro: Lumen Juris, 2009.

APEL, Karl Otto. Estudos de moral moderna. Trad. Benno Dischinger. Petrópolis: Vozes, 1994.

. Transformação da filosofia. O a priori da comunidade de comunicação". Trad. Paulo Astor Soethe. São Paulo: Loyola, 2000. v. II.

AQUINO, São Tomás. Suma Teológica. Tradução de Alexandre Corrêa. 2. ed. Porto Alegre: Escola Superior de Teologia São Lourenço de Brindes, Livraria Sulina Editora; Caxias do Sul: Universidade de Caxias do Sul, 1980. v. V-VI.

BITTAR, Eduardo Carlos Bianca; ALMEIDA, Guilherme Assis de. Curso de Filosofia do Direito. 8. ed. São Paulo: Atlas, 2010.

COMPARATO, Fábio Konder. A afirmação Histórica dos Direitos Humanos. São Paulo: Saraiva, 1999.

DWORKIN, Ronald. Levando os direitos a sério. Trad. Nelson Boeira. Sáo Paulo: Martins Fontes, 2007a.

. O império do direito. Trad. Luiz Camargo Paulo. São Paulo: Martins Fontes, $2007 \mathrm{~b}$.

FERRAJOLI, Luigi. Derecho y Razón. Traucción de Perfecto Ibáñez et el. Madrid: Trotta, 1995.

GOLDSCHMIDT, James. Problemas Jurídicos y Políticos del Proceso Penal. Barcelona: Bosch, 1935.

HABERMAS, Jürgen. Direito e Democracia: entre facticidade e validade. Trad. Flávio Beno Siebeneichler. Rio de Janeiro: Tempo Brasileiro, 1997a. v. 1.

. Direito e Democracia: entre facticidade e validade. Trad. Flávio Beno Siebeneichler. Rio de Janeiro: Tempo Brasileiro, 1997b. v. 2.

. Entre naturalismo e Religiáo. Estudos Filosóficos. Trad. Flávio Beno Siebeneichler. Rio de Janeiro: Tempo Brasileiro, 2007.

. Teoria do agir comunicativo. Racionalidade da ação e racionalidade social. Trad. Paulo Astor Soethe. São Paulo: Martins Fontes, 2012a. v. I. 
- Teoria do agir comunicativo. Sobre a crítica da razão funcionalista. Trad. Flávio Beno Siebeneichler. São Paulo: Martins Fontes, 2012b. v. II.

. Conhecimento e interesse. Trad. Luiz Repa. São Paulo: Unesp, 2014.

HERRERO, Francisco Javier; NIQUET, Marcel (Eds.). Ética do discurso: novos desenvolvimentos e aplicaçóes. São Paulo: [s.n.: s.d.].

KUHLMANN. Wolfgang. Problemas de Fundamentação da Ética do Discurso. In: HERRERO, Francisco Javier; NIQUET, Marcel (Eds). Ética do discurso: novos desenvolvimentos e aplicaçôes. São Paulo: [s.n.: s.d.]. p. 39-69.

JUSTINIANO, Flávio. El Digesto de Justiniano. Tradução de Álvaro d'Ors F. Hernández; P. Fuenteseca; J. Burillo. Pamplona: Aranzade, 1972. t. II.

LOPES JÚNIOR, Aury. Introdução crítica ao Processo Penal: Fundamentos da Instrumentalidade Constitucional. Rio de Janeiro: Lumen Juris, 2006.

MACINTYRE, Alasdair. Justiça de quem? Qual racionalidade? Tradução de Marcelo Pimenta Marques. São Paulo: Loyola, 1991.

PITTA, José Pereira de Paiva. A Ignorância ou Erro de Direito. Coimbra: Imprensa da Universidade, 1871.

TORREL, Jean-Pierre. La Summa di San Tommaso. Traduzione di Patrizia Conforti. Milano: Jaca Books, 2003. 